\title{
Bowel Obstruction Indicator
}

National Cancer Institute

\section{Source}

National Cancer Institute. Bowel Obstruction Indicator. NCI Thesaurus. Code C156503.

An indication as to whether bowel obstruction has occurred. 